\title{
4: 76912750-76861526
}

National Cancer Institute

\section{Source}

National Cancer Institute. 4: 76912750-76861526. NCI Thesaurus. Code C41935.

Physical location of CDKL2_Gene 